\title{
Spectrophotometric Determination of Metronidazole by Prior Reduction and Subsequent Diazotisation and Coupling with N-(1-naphthyl)ethylenediamine-Application to Pharmaceutical Preparations
}

\author{
Wallada H. Ibrahim \\ Wadala A. Bashir \\ Department of Chemistry \\ College of Science \\ University of Mosul
}

(Received 11/10/2011;Accepted 26/12/2011)

\begin{abstract}
A simple, rapid and sensitive spectrophotometric method for the determination of microgram amounts of metronidazole (MZ) has been proposed. The method is based on the reduction of metronidazole with iron metal and hydrochloric acid followed by diazotisation and coupling with $\mathrm{N}$-(1-naphthyl)ethylenediamine in acidic medium to give a pinkish-red colored azo dye which has maximum absorption at $503 \mathrm{~nm}$. Beers law is obeyed in the concentration range of 20-500 $\mu \mathrm{g}$ of metronidazole in a final volume of $25 \mathrm{ml}$, i.e., $0.8-20 \mathrm{ppm}$, with a molar absorptivity of $4.673 \times 10^{3} 1 . \mathrm{mol}^{-1} \cdot \mathrm{cm}^{-1}$ and Sandell's sensitivity index of $0.0366 \mu \mathrm{g} . \mathrm{cm}^{-2}$, a relative error of -1.73 to $+1.58 \%$ and relative standard deviation of \pm 0.47 to $\pm 1.32 \%$, depending on the concentration level. The method has been applied successfully to the determination of metronidazole in pharmaceutical preparations.
\end{abstract}

Keywords: Metronidazole, reduction, diazotization-coupling, N-(1-naphthyl) ethylenediamine reagent, spectrophotometry, assay, pharmaceutical preparations.

القحير الالي الميترونيدازطل بالختزل المسق متبوعا بالازوتة ولافتران مع كاثف N - 1 - فثل) الثيلين شائي المين والظلبق على المستحضرات الصيدلانية

\section{الملغص}

قم اقتراحطريقة بسيطة وسريعة ومسلسة لقدير كميت مايكروغرلمية من دواء الميترونيدازول.

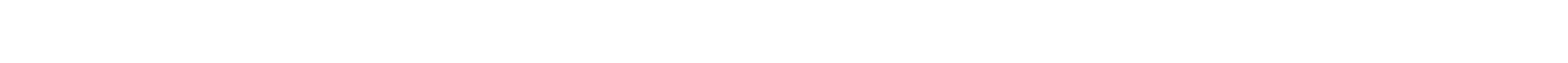
واقتران مع كلثف N- (1 - نفثل) اثيلين ثنائي لمين في محط حلمضي لتكوين صبغة ورية محمرة لها اعلى لمتصاص عند الطول الموجي 503 نانوميتر. وكلن قانون بير خاضعا في مدى التركيز (20 - 500) 
مايكروغرلم من الميترونيدازول في حجم نهائي 25 aل، وهذا يعني 0.8 -20 جزء/مليون بمعلل لمتصاص

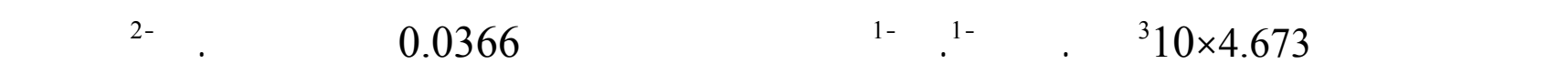

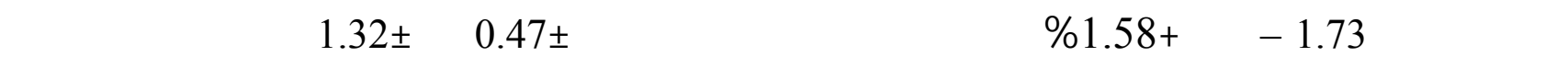
التركيز. قم قبيق الطريقة بنجاح في ققدير الميترونيدازول في المستحضرات الصيدلانية.

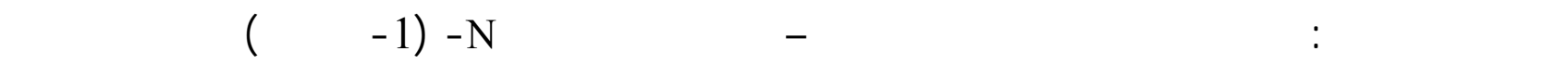
الامين،طريقةطيفية، ظبيقلت على مستحضرات صيدلاني

\section{INTRODUCTION}

Metronidazole (MZ) has a bacterial action against anaerobic bacteria, its spectrum of activity includes the anaerobic gram negative bacilli which include most of Bacteroides such as Fusobacterium and Veillonella, anaerobic gram positive cocci such as Peptococcus and Peptidostreptococcus species and anaerobic gram positive bacilli which include Clostridium and Eubacterium species. (Block et al., 2004).

Chemically MZ is 1 - ( $\beta$ - hydroxyethyl) - 2- methyl-5- nitroimidazole (Sweetman, 2009)

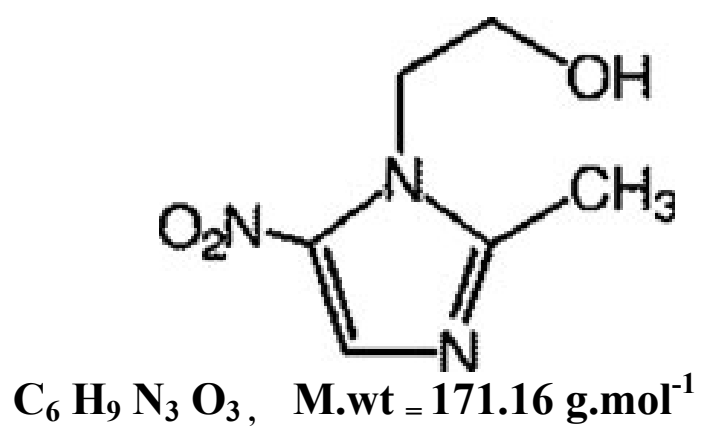

Different methods have been reported for the determination of metronidazole and most of which have been applied to assay in dosage forms. These including: voltammetry (Manohara et al., 2010), spectrophotometry (Adegoke and Bourne, 2009), chromatography (Nora, 2007), polarography (Bartlett, 2005), gas chromatography (Safwan, 2010), and flow injection analysis.(Simone, 2006). The non aqueous titration method using perchloric acid as titrant and determining the end -point potentiometrically for the assay of metronidazole has also been described (British pharmacopoia, 2000).

Most of the spectrophotometric methods found in the literature for the determination of metronidazole are in the visible region and involve initial reduction by treatment with $\mathrm{Zn}$ powder and $\mathrm{HCl}$ (Manohara et al., 2010), followed by the diazotisation and coupling of the resulting amine with different coupling agents such as: 4-chloro-3-nitroaniline (Thulasamma and Venkateswarlu, 2009), 3-methylbenzothiazolin-2-one hydrazone (Nagaraja et al., 2002), p-benzoquinone (Atta et al., 2005), 8-quinolinol (Saffaj et al., 
2004), and $\beta$-naphthol (Charrouf et al., 2004). Various chromatographic methods have been reported for the analysis of metronidazole in pharmaceutical dosage form and biological fluids (Mustapha et al., 2006). High performance liquid chromatography (HPLC) method was employed to measure metronidazole in human plasma and application to single dose pharmacokinetic and bioequivalence studies (Jaber et al., 2006). The objective of the investigation reported in this paper was to evaluate a simple spectrophotometric method for the determination of metronidazole; the method involves the diazotisation of reduced metronidazole followed by subsequent coupling with $\mathrm{N}-(1$-naphthyl)ethylenediamine dihydrochloride (N-NED) to form a highly coloured dye.

\section{Apparatus}

\section{EXPERIMENTAL}

CECIL CE7200 UV-Visible Recording Spectrophotometer UV-160 with $1.0 \mathrm{~cm}$ matched quartz cells were used for all absorption measurements.

\section{Reagent}

All chemicals used were of analytical-reagent grade.

\section{Reduced metronidazole solution $(500 \mu \mathrm{g} / \mathrm{ml})$.}

A $\quad 0.05 \mathrm{~g}$ of metronidazole (NDI,Iraq) is dissolved in about $10 \mathrm{ml}$ distilled water followed by addition of $0.4 \mathrm{~g}$ of powdered iron and $5 \mathrm{ml}$ of concentrated $\mathrm{HCl}$ then the solution is cooled, and filtered, the clear mixture is then transferred to a $100-\mathrm{ml}$ volumetric flask and is completed to the mark with distilled water . The solution is kept in a brown bottle, where it is stable for 2 days.

Reduced working metronidazole solution $(200 \mu \mathrm{g} / \mathbf{m l})$. A $40 \mathrm{ml}$ of $\quad(500 \mathrm{ug} / \mathrm{ml})$ is diluted with distilled water to the mark in a 100- $\mathrm{ml}$ volumetric flask.

Hydrochloric acid solution(1M). This solution is prepared by diluting $8.47 \mathrm{ml}$ of the concentrated acid (Fluka) to the mark with distilled water in a 100- ml volumetric flask.

Sodium nitrite solution( $\mathbf{1 \%}$ ). This solution is prepared by dissolving $1 \mathrm{~g}$ of sodium nitrite $(\mathrm{BDH})$ in distilled water and the volume is completed to the mark in a 100-ml volumetric flask.

Sulphamic acid solution( $\mathbf{3 \%}$ ). This solution is prepared by dissolving $3 \mathrm{~g}$ of sulphamic acid (Fluka) in distilled water and the volume is completed to the mark in a 100-ml volumetric flask.

N-(1-naphthyl)ethylenediamine dihydrochloride (N-NED) solution( $\mathbf{0 . 1 \%})$. This solution is prepared by dissolving $0.1 \mathrm{~g}$ of the compound (Molekula, UK) in distilled water and the volume is completed to the mark in a $100-\mathrm{ml}$ volumetric flask.

Reduced metronidazole tablets solution $(500 \mu \mathrm{g} / \mathrm{ml})$. Weigh and mix the contents of ten tablets(each one contains $500 \mathrm{mg} \mathrm{MZ}$ ), then an accurately weighed amount of powder equivalent to $0.05 \mathrm{~g} \mathrm{MZ}$ was dissolved in $10 \mathrm{ml}$ of distilled water, then the procedure of 
reduction is followed as above. After filtration of the solution, a suitable aliquot of solution was taken and the recommended procedure was followed for analysis of the drug.

Reduced metronidazole suspension solution $(500 \mu \mathrm{g} / \mathbf{m l})$. The suspension solution is shaken very well and $1.25 \mathrm{ml}$ was taken (equivalent to $200 \mathrm{mg} \mathrm{MZ}$ ) with $10 \mathrm{ml}$ distilled water and the procedure for reduction was followed as above; a suitable aliquot of solution was taken and the recommended procedure was followed for analysis of the drug.

Reduced metronidazole injection solution $(500 \mu \mathrm{g} / \mathrm{ml}) .10 \mathrm{ml}$ of the solution was taken (equivalent to $500 \mathrm{mg} \mathrm{MZ}$ ) with $10 \mathrm{ml}$ distilled water and the procedure for reduction was followed as above. a suitable aliquot of solution was taken and the recommended procedure was followed for analysis of the drug.

\section{RESULTS AND DISCUSSION}

For the subsequent experiments, $200 \mu \mathrm{g}$ of metronidazole is taken in $25 \mathrm{ml}$ final volumes and absorbance measurements are performed at $503 \mathrm{~nm}$.

\section{Principle of the method}

The method included the following steps:

Reduction of metronidazole (Denniston et al., 2004):

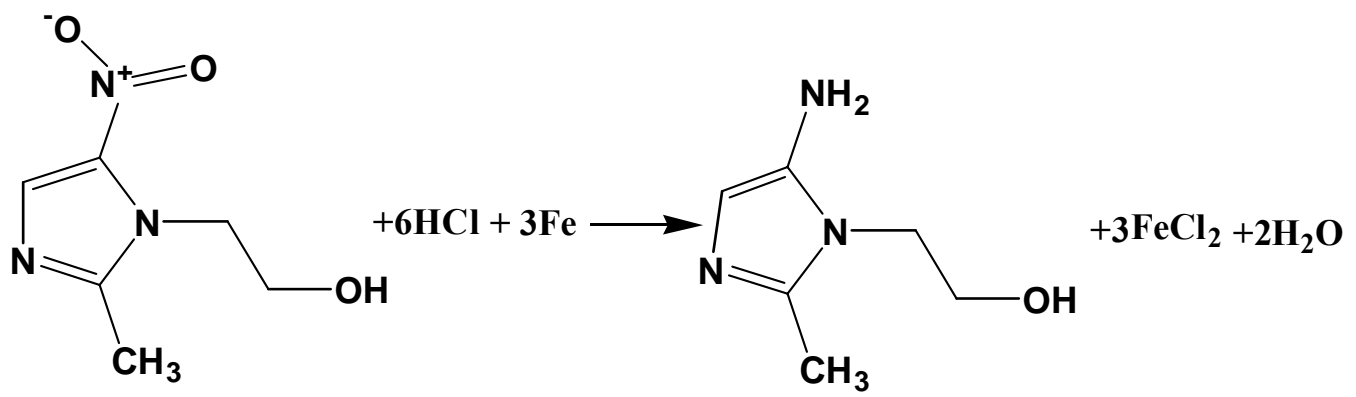

Reduced metronidazole is reacted with excess nitrite in acidic medium to form the diazonium ion :

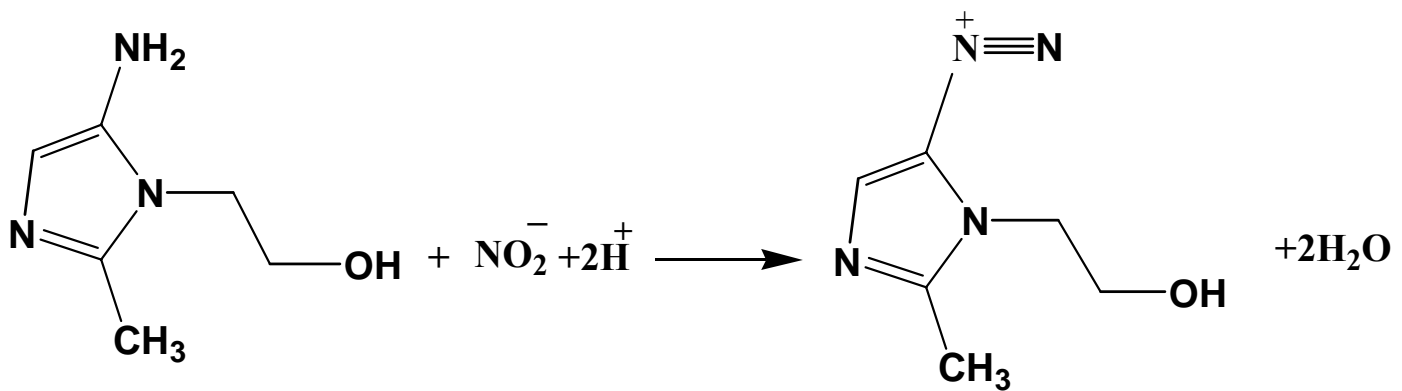

The residual nitrite (as nitrous acid) which was undesirable due to its side reaction, such as, nitrosation of coupling agent (Bladyga et al., 1999), was be removed by sulphamic acid:

$$
\mathrm{HNO}_{2}+\mathrm{H}_{2} \mathrm{NSO}_{3} \mathrm{H} \longrightarrow \mathrm{N}_{2} \mathrm{~A}^{\uparrow}+\mathrm{H}_{2} \mathrm{SO}_{4}+\mathrm{H}_{2} \mathrm{O}
$$
medium.

The colored solution is formed by coupling diazotized MZ with N-NED in acidic 

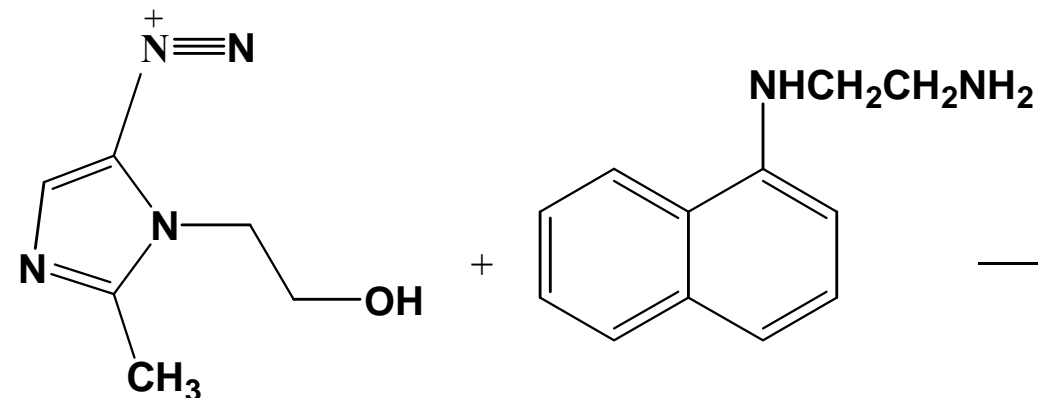

pinkish-red azo dye

\section{Study of the optimum reaction conditions}

The various parameters affecting the colour intensity of the dye have been studied and optimum conditions are selected.

\section{Choice of coupling agent}

Different coupling agents are used for the reaction with diazotized reduced metronidazole in acidic medium. The results in Table 1 show that N-NED gives the more sensitive reaction $\left(\varepsilon=4.986 \times 10^{3} 1 . \mathrm{mol}^{-1} . \mathrm{cm}^{-1}\right)$ in acidic medium.

Table 1: Selection of coupling agent.

\begin{tabular}{|l|c|c|c|c|}
\hline \multicolumn{1}{|c|}{ Reagents 1\% } & Absorbance & $\boldsymbol{\lambda} \mathbf{m a x}(\mathbf{n m})$ & $* \boldsymbol{\Delta \lambda \mathbf { n m }}$ & $\boldsymbol{\varepsilon}\left(\mathbf{l} . \mathbf{m o l}^{\mathbf{- 1}} \cdot \mathbf{c m}^{\mathbf{- 1}}\right)$ \\
\hline 4-aminobenzophenone & 0.06 & 435 & 45 & $1.284 \times 10^{3}$ \\
\hline 4-aminoantipyrine & 0.102 & 335 & 25 & $2.183 \times 10^{3}$ \\
\hline 3,5-diaminobenzoic acid & $* *$ & $* *$ & $* *$ & $* *$ \\
\hline 1,5-naphthalenediamine & $* *$ & $* *$ & $* *$ & $* *$ \\
\hline N-NED & 0.233 & 503 & 99 & $4.986 \times 10^{3}$ \\
\hline promethazine & $* *$ & $* *$ & $* *$ & $* *$ \\
\hline
\end{tabular}

$* \Delta \lambda=$ colour contrast $=\lambda \max _{\mathrm{S}}-\lambda \max _{\mathrm{B}}$, Where $\mathrm{S}=$ The dye, $\mathrm{B}=\mathrm{Blank}$

**: no colour contrast

\section{Effect of N-NED amount}

The effect of different N-NED amount on the colour intensity of the dye has been studied ( Table 2).

Table 2: Effect of N-NED amount.

\begin{tabular}{|c|c|c|c|c|c|c|}
\hline \multirow{2}{*}{$\begin{array}{c}\text { ml of N-NED } \\
(0.1 \%) \text { soln. }\end{array}$} & \multicolumn{5}{|c|}{ Absorbance/ $\mu \mathrm{g}$ of reduced metronidazole } & \multirow{2}{*}{$\mathbf{R}^{2}$} \\
\hline & 50 & 100 & 200 & 300 & 500 & \\
\hline 1.0 & 0.038 & 0.076 & 0.138 & 0.197 & 0.310 & 0.9982 \\
\hline 3.0 & 0.025 & 0077 & 0.154 & 0.201 & 0.360 & 0.9933 \\
\hline 5.0 & 0.062 & 0.119 & 0.229 & 0.331 & 0.558 & 0.9997 \\
\hline 7.0 & 0.051 & 0.109 & 0.219 & 0.288 & 0.491 & 0.9962 \\
\hline 10.0 & 0.053 & 0.11 & 0.21 & 0.281 & 0.448 & 0.9956 \\
\hline
\end{tabular}


From the results, it can be observed that $5 \mathrm{ml}$ of $0.1 \% \mathrm{~N}-\mathrm{NED}$ solution is the more suitable amount which gives the highest value of formed azo dye absorbance and also it gives highest determination coefficient $\left(\mathrm{R}^{2}\right)$ values.

\section{Effect of acids on the diazotization}

The effect of the amount of different acids (weak and strong) used for the diazotisation of reduced $\mathrm{MZ}$ has been investigated. The results indicated that $2 \mathrm{ml}$ of $1 \mathrm{M}$ $\mathrm{HCl}$ gives the highest colour intensity therefore, it has been selected in subsequent experiments (Table 3 ).

Table 3: Effect of acid type and its amount on absorbance of dye.

\begin{tabular}{|c|c|c|c|c|c|c|c|}
\hline \multirow{2}{*}{$\begin{array}{c}\text { Acid used } \\
(\mathbf{1 M )}\end{array}$} & \multicolumn{7}{|c|}{ Absorbance / ml of acid used } \\
\cline { 2 - 8 } & $\mathbf{0}$ & $\mathbf{0 . 5}$ & $\mathbf{1}$ & $\mathbf{2}$ & $\mathbf{3}$ & $\mathbf{4}$ & $\mathbf{5}$ \\
\hline $\mathbf{H C l}$ & 0.044 & 0.161 & 0.178 & 0.226 & 0.189 & 0.181 & 0.179 \\
\hline $\mathbf{H}_{\mathbf{2}} \mathbf{S O}_{\mathbf{4}}$ & 0.046 & 0.133 & 0.143 & 0.140 & 0.139 & 0.134 & 0.130 \\
\hline $\mathbf{H N O}_{\mathbf{3}}$ & 0.044 & 0.123 & 0.135 & 0.131 & 0.121 & 0.129 & 0.122 \\
\hline $\mathbf{C H}_{\mathbf{3}} \mathbf{C O O H}$ & 0.043 & 0.138 & 0.148 & 0.141 & 0.138 & 0.137 & 0.134 \\
\hline $\mathbf{H}_{\mathbf{3}} \mathbf{P O}_{\mathbf{4}}$ & 0.045 & 0.144 & 0.156 & 0.145 & 0.137 & 0.135 & 0.133 \\
\hline
\end{tabular}

\section{Effect of nitrite amount and time}

The colored dye reached its maximum intensity when using $1 \mathrm{ml}$ of $1 \%$ sodium nitrite solution after 5 minutes as a reaction standing time ( Table 4).

Table 4: The effect of sodium nitrite amount and time on dye absorbance.

\begin{tabular}{|c|c|c|c|c|c|c|c|}
\hline \multirow{2}{*}{$\begin{array}{c}\text { ml of(1\%)NaNO } \\
\text { solution }\end{array}$} & \multicolumn{7}{|c|}{ Absorbance / minute standing time } \\
\cline { 2 - 8 } & $\mathbf{0}$ & $\mathbf{1}$ & $\mathbf{2}$ & $\mathbf{3}$ & $\mathbf{5}$ & $\mathbf{7}$ & $\mathbf{1 0}$ \\
\hline $\mathbf{0}$ & 0.004 & 0.006 & 0.005 & 0.004 & 0.007 & 0.006 & 0.006 \\
\hline $\mathbf{0 . 1}$ & 0.125 & 0.155 & 0.161 & 0.176 & 0.171 & 0.163 & 0.159 \\
\hline $\mathbf{0 . 3}$ & 0.145 & 0.166 & 0.172 & 0.175 & 0.168 & 0.163 & 0.158 \\
\hline $\mathbf{0 . 5}$ & 0.147 & 0.155 & 0.161 & 0.166 & 0.169 & 0.162 & 0.159 \\
\hline $\mathbf{0 . 7}$ & 0.153 & 0.163 & 0.169 & 0.174 & 0.173 & 0.167 & 0.160 \\
\hline $\mathbf{1 . 0}$ & 0.169 & 0.187 & 0.198 & 0.210 & 0.228 & 0.192 & 0.188 \\
\hline $\mathbf{1 . 5}$ & 0.151 & 0.161 & 0.164 & 0.166 & 0.168 & 0.162 & 0.155 \\
\hline
\end{tabular}




\section{Effect of sulphamic acid amount and time}

The presence of unreacted nitrite is undesirable in diazotisation reaction. Therefore, it should be removed by sulphamic acid which rapidly reacts with nitrite. The results indicated that $1 \mathrm{ml}$ of $3 \%$ sulphamic acid solution with 3 minutes standing time are considered to be the most suitable (Table 5), and therefore are selected subsequently.

Table 5: The effect of sulphamic acid amount and time on the dye absorbance.

\begin{tabular}{|c|c|c|c|c|c|c|c|}
\hline \multirow{2}{*}{$\begin{array}{c}\text { ml of sulphamic } \\
\text { acid } \\
\text { solution }(3 \%)\end{array}$} & \multicolumn{7}{|c|}{ Absorbance / minute standing time } \\
\hline & & $\mathbf{0}$ & 1 & 2 & 3 & 5 & 10 \\
\hline \multirow[t]{2}{*}{$\mathbf{0 . 0}$} & Sample & $*$ & $*$ & $*$ & $*$ & $*$ & $*$ \\
\hline & Blank $=B$ & 1.848 & 1.475 & 1.328 & 1.322 & 1.292 & 1.21 \\
\hline \multirow{2}{*}{0.1} & $\mathbf{S}$ & $*$ & $*$ & $*$ & $*$ & $*$ & $*$ \\
\hline & B & 1.77 & 1.35 & 1.26 & 1.24 & 1.21 & 1.19 \\
\hline \multirow{2}{*}{0.3} & $\mathbf{S}$ & $*$ & $*$ & $*$ & $*$ & $*$ & $*$ \\
\hline & B & 1.54 & 1.51 & 1.44 & 1.36 & 1.32 & 1.30 \\
\hline \multirow{2}{*}{0.5} & $\mathbf{S}$ & 0.078 & 0.112 & 0.120 & 0.129 & 0.115 & 0.109 \\
\hline & B & 0.089 & 0.067 & 0.061 & 0.062 & 0.065 & 0.068 \\
\hline \multirow{2}{*}{0.7} & $\mathbf{S}$ & 0.123 & 0.133 & 0.138 & 0.141 & 0.136 & 0.134 \\
\hline & B & 0.033 & 0.035 & 0.038 & 0.030 & 0.041 & 0.043 \\
\hline \multirow{2}{*}{1.0} & $\mathbf{S}$ & 0.135 & 0.167 & 0.189 & 0.226 & 0.201 & 0.186 \\
\hline & B & 0.020 & 0.019 & 0.018 & 0.019 & 0.017 & 0.018 \\
\hline \multirow{2}{*}{1.5} & $\mathbf{S}$ & 0.122 & 0.128 & 0.132 & 0.131 & 0.128 & 0.119 \\
\hline & B & 0.016 & 0.017 & 0.017 & 0.016 & 0.018 & 0.019 \\
\hline \multirow{2}{*}{2.0} & $\mathbf{S}$ & 0.123 & 0.129 & 0.120 & 0.113 & 0.103 & 0.110 \\
\hline & B & 0.017 & 0.016 & 0.018 & 0.019 & 0.017 & 0.015 \\
\hline
\end{tabular}

* negative absorbance values.

\section{Effect of time and amount of MZ on absorbance}

The effect of time on the development and stability period of the formed colored dye was investigated under optimum experimental conditions described before. The formation of colored dye being complete after mixing the components of the reaction and the absorbance of the colored species remained constant for at least 75 minutes (Table 6). 
Table 6: The effect of time on absorbance.

\begin{tabular}{|c|c|c|c|}
\hline \multirow{2}{*}{ Time, minutes } & \multicolumn{3}{|c|}{ Absorbance/ $\mathbf{\mu g}$ of MZ/ 25 ml } \\
\cline { 2 - 4 } & $\mathbf{1 0 0}$ & $\mathbf{2 0 0}$ & $\mathbf{5 0 0}$ \\
\hline $\mathbf{5}$ & 0.126 & 0.240 & 0.563 \\
\hline $\mathbf{1 0}$ & 0.122 & 0.232 & 0.558 \\
\hline $\mathbf{1 5}$ & 0.121 & 0.231 & 0.559 \\
\hline $\mathbf{2 0}$ & 0.121 & 0.232 & 0.559 \\
\hline $\mathbf{2 5}$ & 0.120 & 0.231 & 0.558 \\
\hline $\mathbf{3 0}$ & 0.121 & 0.233 & 0.559 \\
\hline $\mathbf{3 5}$ & 0.122 & 0.232 & 0.560 \\
\hline $\mathbf{4 0}$ & 0.121 & 0.230 & 0.558 \\
\hline $\mathbf{4 5}$ & 0.120 & 0.231 & 0.560 \\
\hline $\mathbf{5 0}$ & 0.121 & 0.231 & 0.561 \\
\hline $\mathbf{5 5}$ & 0.120 & 0.232 & 0.559 \\
\hline $\mathbf{6 0}$ & 0.121 & 0.230 & 0.560 \\
\hline $\mathbf{9 0}$ & 0.121 & 0.231 & --- \\
\hline
\end{tabular}

\section{Effect of order of addition}

The results indicated that the effect of order of addition (Table 7) of reagents is important:

Table 7: Effect of order of addition of reagents.

\begin{tabular}{|l|c|}
\hline \multicolumn{1}{|c|}{ order } & absorbance \\
\hline $\mathrm{MZ}+\mathrm{HCl}+\mathrm{NaNO}_{2}+$ sulphamic acid $+\mathrm{N}-\mathrm{NED}$ & 0.229 \\
\hline $\mathrm{MZ}+\mathrm{NaNO}_{2}+\mathrm{HCl}+$ sulphamic acid $+\mathrm{N}-\mathrm{NED}$ & 0.163 \\
\hline $\mathrm{MZ}+\mathrm{HCl}+$ sulphamic acid $+\mathrm{NaNO}_{2}+\mathrm{N}-\mathrm{NED}$ & 0.044 \\
\hline $\mathrm{MZ}+$ sulphamic acid $+\mathrm{HCl}+\mathrm{NaNO}_{2}+\mathrm{N}-\mathrm{NED}$ & 0.023 \\
\hline $\mathrm{MZ}+\mathrm{NaNO}_{2}+$ sulphamic acid $+\mathrm{HCl}+\mathrm{N}-\mathrm{NED}$ & 0.145 \\
\hline $\mathrm{MZ}+\mathrm{NaNO}_{2}+$ sulphamic acid $+\mathrm{N}-\mathrm{NED}+\mathrm{HCl}$ & $0.213\left(\boldsymbol{\lambda}_{\max }=460\right)$ \\
\hline
\end{tabular}

From the orders cited above, we can conclude that the reaction of nitrite with sulphamic acid is faster than the reaction of nitrite with reduced metronidazole and hence an absorbance decrease is observed. The last order reveals that nitrite will nitrosate N-NED to form the nitroso derivative which might be yellow to orange in colour, depending on the nature of the amine. 


\section{Final absorption spectra}

Absorption spectra of the colored dye formed by coupling of diazotized reduced $\mathrm{MZ}$ with N-NED reagent in acidic medium was recorded against its corresponding reagent blank and show a maximum absorption at $503 \mathrm{~nm}$ in contrast to the N-NED reagent blank which shows no absorption in the visible region (Fig. 1).

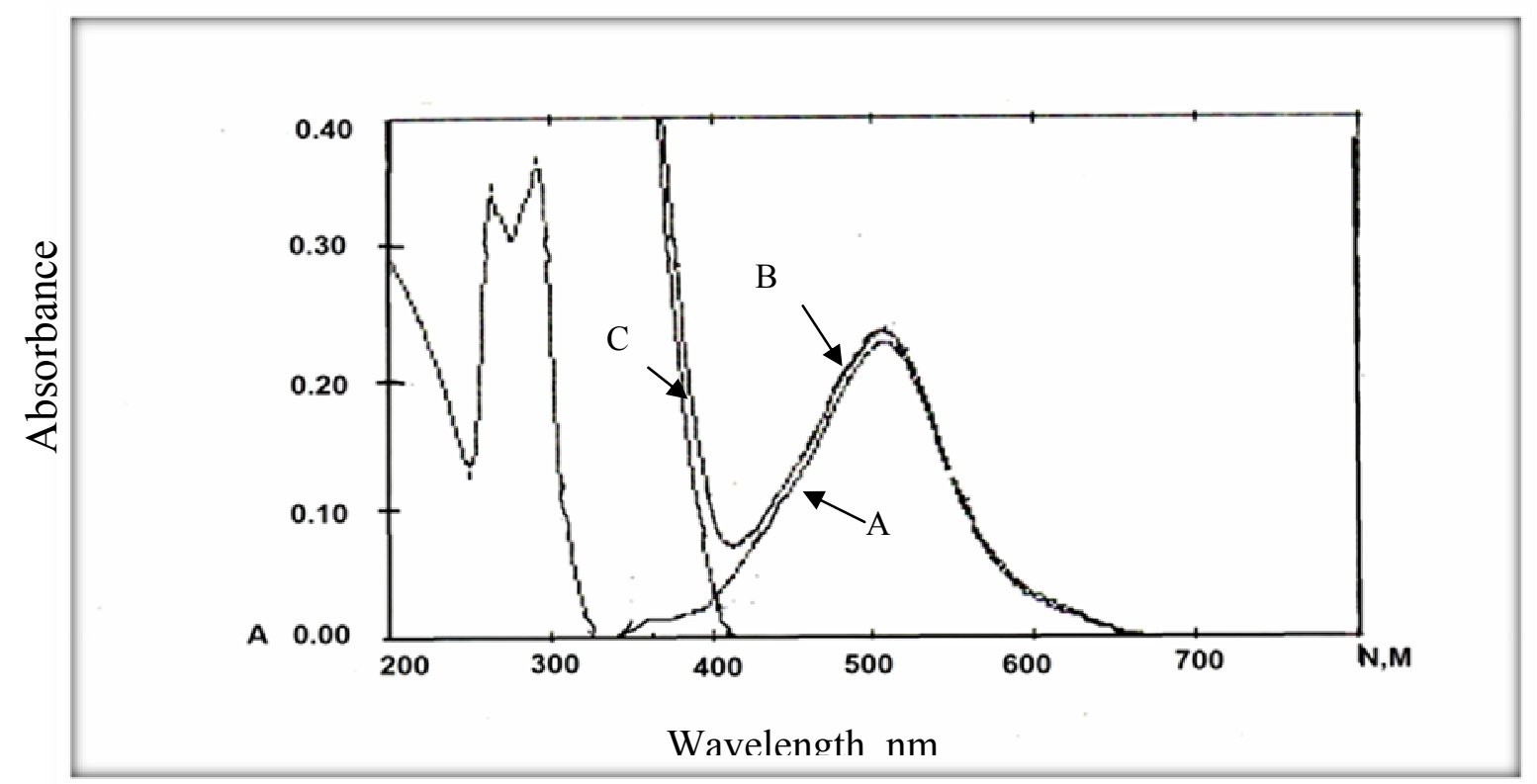

Fig. 1: Absorption spectra of $200 \mu \mathrm{g} M \mathrm{MZ}$ treated according to the recommended procedure and measured against (A) blank, (B) distilled water and (C) blank measured against distilled water

\section{Procedure and calibration graph :}

To a series of 25-ml calibrated flasks, an aliquot of aqueous solution containing $20-$ $500 \mu \mathrm{g}$ Of reduced $\mathrm{MZ}$ are transferred, $1 \mathrm{ml}$ of $1 \mathrm{M}$ hydrochloric acid is added and the mixture is shaken, then $1 \mathrm{ml}$ of $1 \%$ sodium nitrite solution is added and the mixture is allowed to stand for 5 minutes then $1 \mathrm{ml}$ of 3\% sulphamic acid solution is added with occasional shaking for 3 minutes. A $5 \mathrm{ml}$ of $0.1 \% \mathrm{~N}-\mathrm{NED}$ solution is added and the volumes are completed to the mark with distilled water, the absorbances are read at $503 \mathrm{~nm}$ against blank. The colour was stable for at least 1 hour. The calibration graph is linear over the range $0.8-20 \mathrm{ppm}$ (Fig.2). The apparent molar absorptivity, referred to MZ, has been found to be $4.673 \times 10^{3} 1 . \mathrm{mole}^{-1} \cdot \mathrm{cm}^{-1}$. 


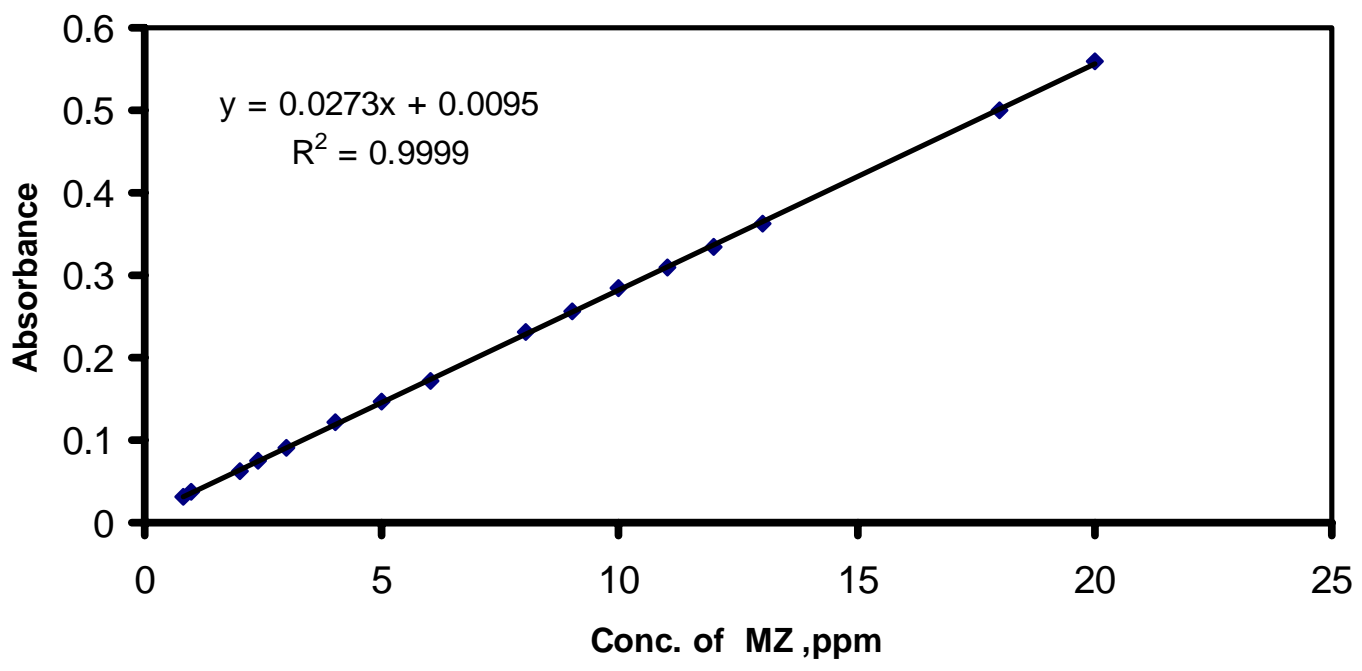

Fig. 2: Calibration graph for MZ determination using N-NED as coupling reagent.

\section{Accuracy and precision}

To check the accuracy and precision of the calibration curve, MZ was determined at three different concentrations. The results illustrated in Table 8 indicate that the method is satisfactory.

Table 8: Accuracy and precision of the calibration curve.

\begin{tabular}{|c|c|c|c|c|}
\hline $\begin{array}{c}\text { ugMZ } \\
\text { Present/ 25 ml }\end{array}$ & $\begin{array}{c}\boldsymbol{\mu g} \text { MZ } \\
\text { measured/25ml }\end{array}$ & Recovery,\%* & $\begin{array}{l}\text { Relative } \\
\text { error, \%* } *\end{array}$ & $\begin{array}{l}\text { Relative } \\
\text { standard } \\
\text { deviation, \%* }\end{array}$ \\
\hline $\mathbf{5 0}$ & 50.1 & 100.2 & +1.58 & \pm .32 \\
\hline $\mathbf{1 0 0}$ & 99.8 & 99.8 & -0.83 & \pm .08 \\
\hline $\mathbf{2 0 0}$ & 199.3 & 99.6 & -1.73 & $\mathbf{\pm} .47$ \\
\hline
\end{tabular}

*Average of five determinations

\section{Nature of the Dye}

Job's method (Hargis, 1988) indicates that the azo dye has a composition of 1:1 [MZ] to N-NED reagent (Fig.3). 


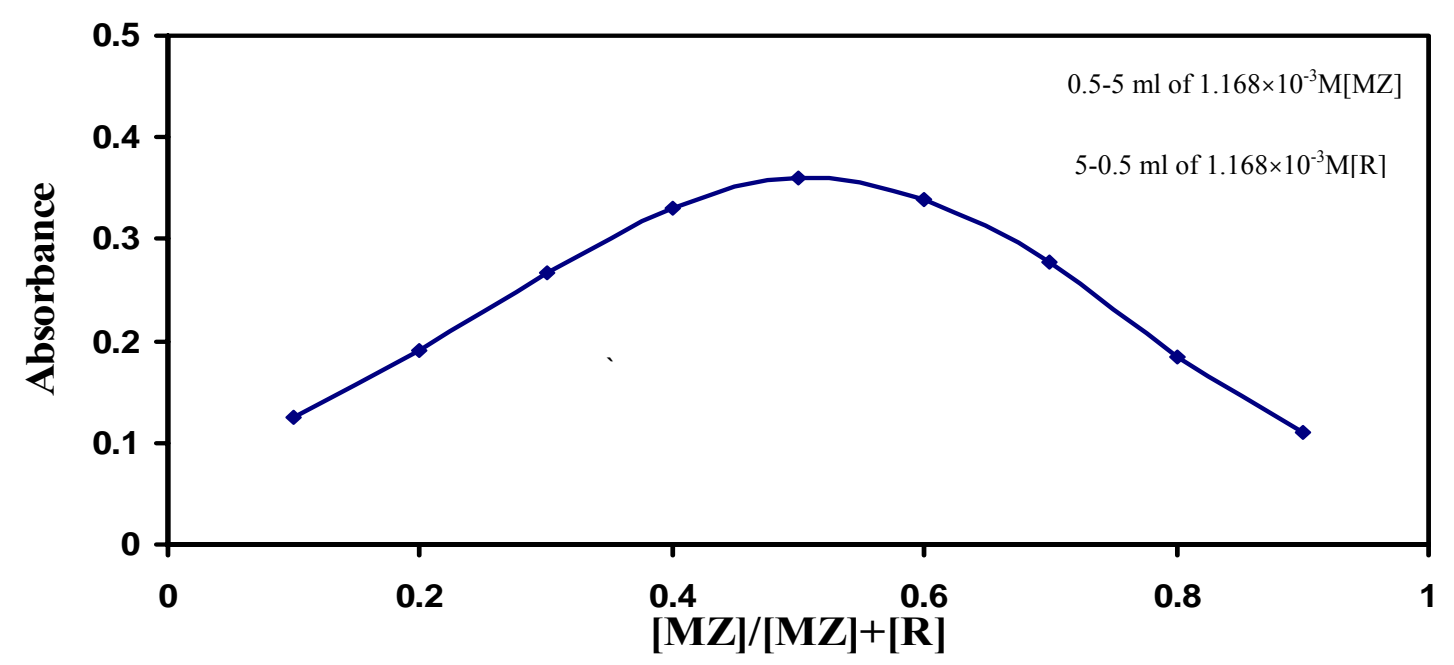

Fig.3: Job's plot for MZ-N-NED.

Which may have the following structure

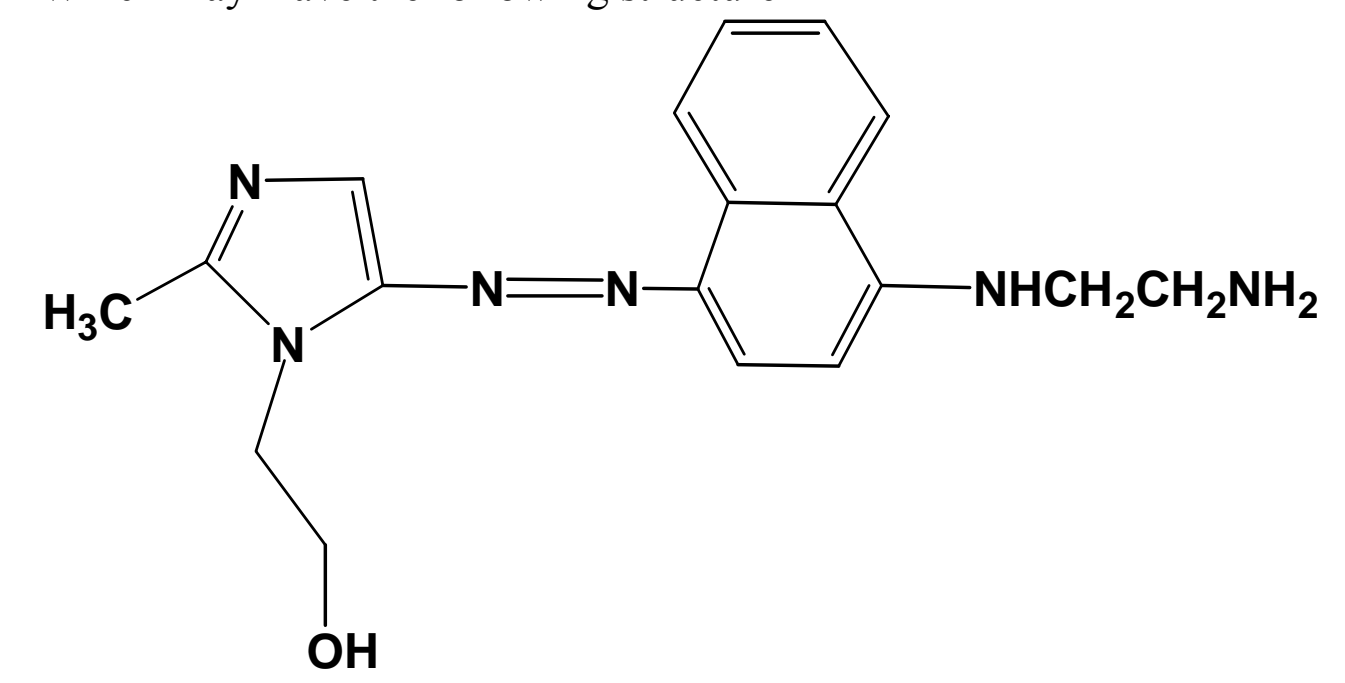

\section{Interference}

The effect of some foreign compounds, which often accompanied pharmaceutical preparations, was studied by adding different amounts to $200 \mu \mathrm{g}$ metronidazole in a final volume $25 \mathrm{ml}$ (Table 9).

Table 9: Effect of excipients on assay of metronidazole

\begin{tabular}{|c|c|c|c|c|}
\hline \multirow{2}{*}{ Interferences } & \multicolumn{4}{|c|}{ Recovery / $\boldsymbol{\mu g}$ of Interferences } \\
\cline { 2 - 5 } & $\mathbf{1 0 0}$ & $\mathbf{2 0 0}$ & $\mathbf{5 0 0}$ & $\mathbf{1 0 0 0}$ \\
\hline Starch & 100.2 & 99.5 & 99.6 & 98.5 \\
\hline Glucose & 100.1 & 100.2 & 99.5 & 98.7 \\
\hline Arabic Gum & 99.8 & 98.3 & 97.6 & 96.8 \\
\hline Lactose & 100.1 & 100.3 & 98.9 & 98.1 \\
\hline
\end{tabular}


The results in Table 9 indicated that the studied foreign compound do not interfere in the determination of metronidazole using the proposed method.

\section{Effect of organic solvents}

Different organic solvents have been examined to evaluate their effects on the spectrum of the resulting azo dye, the results are given in Table 10 and Fig. 5.

Table 10: Effect of organic solvents on optical properties of azo dye.

\begin{tabular}{|c|c|c|c|}
\hline Solvent & Absorbance & $\max , \mathbf{n m} \lambda$ & , l.mol ${ }^{-1} \cdot \mathrm{cm}^{-1} \varepsilon$ \\
\hline Water & 0.228 & 503 & $4.88 \times 10^{3}$ \\
\hline Acetone & Turbid & -------- & -------- \\
\hline Acetic acid & 0.001 & 517.5 & $0.21 \times 10^{2}$ \\
\hline Ethanol & 0.18 & 510 & $3.852 \times 10^{3}$ \\
\hline Formic acid & 0.10 & 511 & $1.926 \times 10^{3}$ \\
\hline Methanol & Turbid & -------- & -------- \\
\hline N,N-Dimethylformamide & Turbid & -------- & -------- \\
\hline Tetrahydrofuran & 0.008 & 511.5 & $1.71 \times 10^{2}$ \\
\hline
\end{tabular}

It can be seen from the above table that water is the best solvent from both economic as well as analytical points of view. Therefore, water is still chosen in the subseqent experiments.

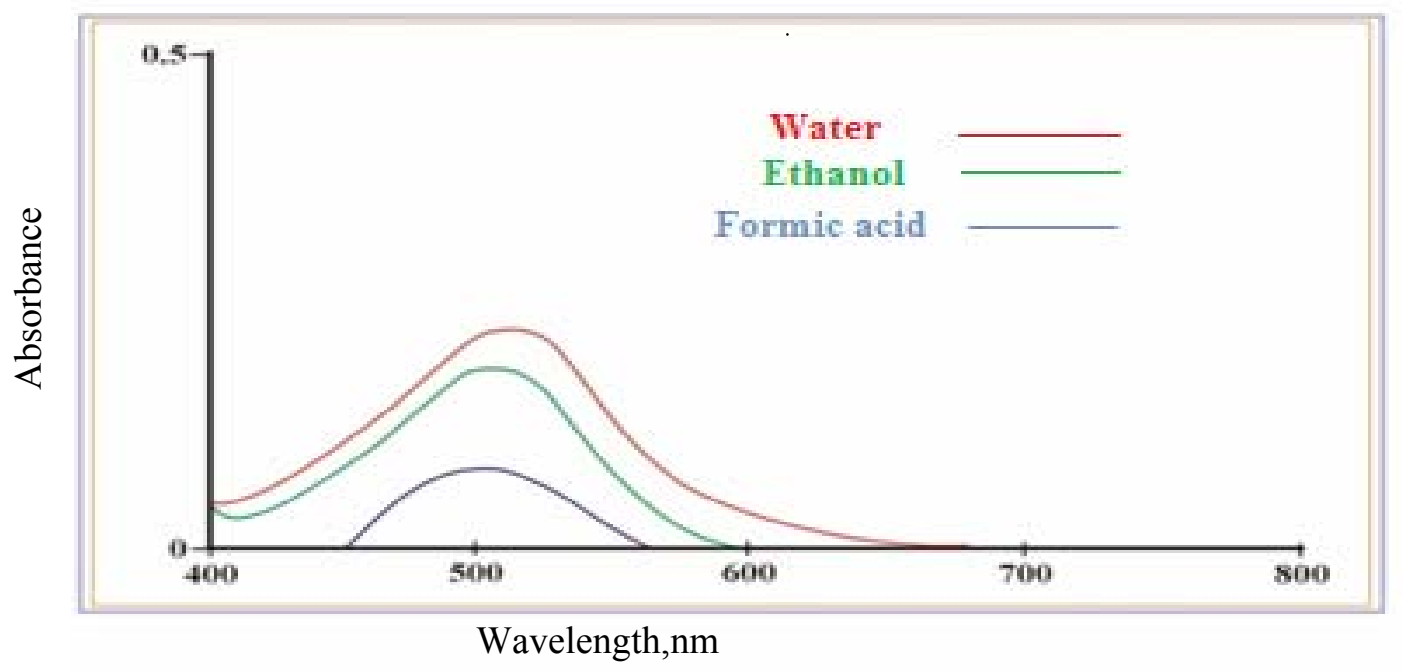

Fig. 5: Effect of organic solvents on optical properties of azo dye 


\section{Application of the Method}

The proposed method was successfully applied to determine metronidazole in its pharmaceutical preparations (Table 11). The performance of the proposed method was assessed by calculation of the t-test compared with the standard method (British Pharmacopeia, 2000) (non aqueous titration with perchloric acid) for $95 \%$ confidence level with four degrees of freedom. The results showed that the $t$-value was less than the critical value $=2.306$, indicated that there was no significant difference between the proposed and standard method for metronidazole (Table 12).

Table 11. Analytical applications of the proposed method.

\begin{tabular}{|c|c|c|c|}
\hline $\begin{array}{c}\text { Pharmaceutical } \\
\text { preparation }\end{array}$ & $\begin{array}{c}\mathrm{gMZ} \boldsymbol{\mu} \\
\text { Present/ } 25 \mathrm{ml}\end{array}$ & $\begin{array}{c}\operatorname{gMZ} \mu \\
\text { measured/ } 25 \mathrm{ml}\end{array}$ & Recovery\%* \\
\hline \multirow{3}{*}{$\begin{array}{c}\text { Metron } 500 \text { mg } \\
\text { Injection } \\
\text { Alkem (INDIA) }\end{array}$} & 50 & 50.16 & 100.3 \\
\hline & 100 & 99.5 & 99.5 \\
\hline & 200 & 197 & 98.5 \\
\hline \multirow{3}{*}{$\begin{array}{l}\text { Flazol fort } 200 \\
\text { mg(suspenstion) } \\
\text { ASIA (SYRIA) }\end{array}$} & 50 & 49 & 98 \\
\hline & 100 & 98.3 & 98.3 \\
\hline & 200 & 200.2 & 100.1 \\
\hline \multirow{3}{*}{$\begin{array}{c}\text { Negazole } \\
500 \text { mg Tablet } \\
\text { Julphar (UAE) }\end{array}$} & 50 & 48.8 & 97.6 \\
\hline & 100 & 99.8 & 99.8 \\
\hline & 200 & 197 & 98.5 \\
\hline \multirow{3}{*}{$\begin{array}{c}\text { MEDAZOLE } \\
\text { 500mg Tablet } \\
\text { S.D.I IRAQ }\end{array}$} & 50 & 49.7 & 99.4 \\
\hline & 100 & 100.2 & 100.2 \\
\hline & 200 & 195.6 & 97.8 \\
\hline
\end{tabular}

*Average of five determinations.

Table 12: The results of t-test analysis.

\begin{tabular}{|c|c|c|c|}
\hline \multirow{2}{*}{$\begin{array}{c}\text { Pharmaceutical } \\
\text { preparation }\end{array}$} & Present method & $\begin{array}{c}\text { British Pharmacopeia } \\
\text { method }\end{array}$ & t. exp \\
\cline { 2 - 4 } $\begin{array}{c}\text { Metron 500 mg } \\
\text { Injection } \\
\text { Alkem (INDIA) }\end{array}$ & 98.5 & 99.4 & 1.16 \\
\hline $\begin{array}{c}\text { Negazole } \\
\text { 500 mg Tablet } \\
\text { Julphar (UAE) }\end{array}$ & 98.5 & 99.2 & 1.84 \\
\hline $\begin{array}{c}\text { MEDAZOLE } \\
\text { 500mg Tablet } \\
\text { S.D.I IRAQ }\end{array}$ & 97.8 & 98.9 & 1.6 \\
\hline
\end{tabular}




\section{Comparison of Method}

Table 13 shows the comparison between the analytical variable obtained from the present method with those of recent spectrophotometric method.

Table 13: Comparison of the methods.

\begin{tabular}{|c|c|c|}
\hline Analytical parameters & Present method & Literature method* \\
\hline Temperature $\left({ }^{\circ} \mathbf{C}\right)$ & At room temperature & At room temperature \\
\hline$\lambda_{\max }(\mathrm{nm})$ & 503 & 480 \\
\hline Medium of method & Aqueous & Aqueous \\
\hline Reducing agent & Iron metal & Zinc metal \\
\hline Coupling Reagent & N-NED & $\begin{array}{l}\text { 4-chloro3-nitro } \\
\text { Aniline }\end{array}$ \\
\hline Beer's law range(ppm) & $0.8-20$ & $5-60$ \\
\hline $\begin{array}{c}\text { Molar absorptivity } \\
\text { (l.mol-1.cm }\end{array}$ & $4.673 \times 10^{3}$ & $2.71 \times 10^{3}$ \\
\hline $\operatorname{RSD}(\%)$ & \pm 0.47 to \pm 1.08 & 2.5 \\
\hline Sandell's sensitivity $\left(\mu \mathrm{g} / \mathrm{cm}^{2}\right)$ & 0.0366 & 0.0632 \\
\hline Nature of the dye & $1: 1$ & $1: 1$ \\
\hline Color of the dye & Pinkish-red & Yellow \\
\hline Application of the method & $\begin{array}{l}\text { Has been applied to } \\
\text { the assay of } \\
\text { metronidazole in } \\
\text { pharmaceutical } \\
\text { preparation (tablets, } \\
\text { injection and } \\
\text { suspenstion) }\end{array}$ & $\begin{array}{l}\text { Has been applied to } \\
\text { the assay of } \\
\text { metronidazole in } \\
\text { pharmaceutical } \\
\text { preparation example: } \\
\text { Metrozyl }\end{array}$ \\
\hline
\end{tabular}

* Thulasamma and Venkateswarlu (2009)

The application of the present method is of wider scope. 


\section{REFERENCES}

Adegoke, O. A.; Umoh O. E. (2009). A new approach to the spectrophotometric determination of metronidazole and tinidazole using pdimethylaminobenzaldhehyde. Acta Pharm., 59(4), 407-419.

Atta - Ur- Rehnan, A. S. Ijaz ; Raza. (2005). Spectrophotometric determination of metronidazole and secnidazole in pharmaceutical preparation. J. Iranian Chem. Soc., 2(3), 197-202.

Bartlett, P. N.; Choneim, E.; El-hefnawy, G.; Hallag, I. EL. (2005). Voltammetry and determination of metronidazole at a carbon fiber microdisk electrode. Talanta , 66 (4), 869-874.

Bladyga, J.; Bourne, J. R. (1999). "Turbulent Mixing and Chemical Reactions." John Wiley and Sons, Inc., New York. 644p.

Block, H. J.; Beale, M. J.; Wilson and Gisvold, S. (2004). "Text-book of Organic Medicinal and Pharmaceutical Chemistry". 11th edn., 260p.

"British pharmacopoia on CD-ROM", (2009). 5th edn., System Simulation Ltd, the Stationary Office, London, pp. 3952-3955.

"British pharmacopoia on CD-ROM". (2000). 3rd edn., System Simulation Ltd, the Stationary Office, London, pp. 917-918.

Charrouf, M.; Abourriche, A.; Aboud, Y.; Bennamara, A.; Saffj, T. (2004). Spectrophotometric determination of metronidazole and secnidazole in pharmaceutical preparations. Laboratoire Dechimie Orgaique Biomoleculare, 2(1), 164-168.

Denniston, K. J.; Topping, J. J.; Caret, R. L. (2004). "General, Organic, and Biochemistry", 4th edn., The Mc Graw-Hill, New York, 466p.

Hargis, L.G. (1988). "Analytical Chemistry: Principles and Techniques". Prentice- Hill, Inc., New Jersey, pp. 424-427.

Jaber, E.; Neda, G.; Hamed, H. (2006). A rapid and sensitive HPLC method for the metronidazole in human plasma: application to single dose pharmacokinetic and bioequivalence studies. Daru., 14 (1), 15-21.

Manohara, Y. N.; Venkatesha, R.; Revathi, R.; Bahlul, Z. (2010). Novel and rapid estimation of metronidazol in tablets. Der Pharma Chemical, 2(3), 148-151 .

Mustapha, K.; Odunola, M.; Garba, M.; Obodozie, O. (2006). Rapid, cost-effective liquid chromatograghic method for the determination of metronidazole in biological fluids. African J. Biotechnol . 5 (13), 1188-1191.

Nagaraja, P.; Sunitha, K. R.; Vasantha, R. A.; Yathirajan, H. S. (2002). Spectrophotometric determination of metronidazole and tinidazole in pharmaceutical preparations. J. Pharm. Biomed. Anal.. 28, 527-535

Nora, H. Al-shaalan, (2007). Determination of diloxanide furoate and metronidazole in binary mixture using first derivative of the ratio- spectra and high-performance liquid chromatography-UV methods. Amer. J. Appl. Sci. , 4(2), 66-72 .

Saffaj, T.; Charrouf, M.; Abourriche, A.; Aboud, Y.; Bennamara, A.; Maoufoud, S.; Berrada, M. (2004). Spectrophotometric determination of metronidazole in pharmaceutical preparations. IL Farmaco. 59 (10) 843-846. 
Safwan, A.; Nuha, K. (2010). Simultaneous determination of miconazole nitrate and metronidazole in different pharmaceutical dosage forms by gas chromatography and flame ionization detector (GC-FID). Intern. J. Biomed. Sci. 6(1), 13-18 .

Simone, S. S.; Everaldo, P. M.; Edvaldo, N. G.; Wellington, S. L.; Pablo, N. T.; Mario, C. U.; Edvan, C. S.; Valbere, N. (2006). Flow injection determination of metronidazole through spectrophotometric measurement of the nitrite ion produced upon alkaline hydrolysis. J. Brazilian Chem. Soc. 17(3).

Sweetman, S. C. (2009). "Martindale, The Complete Drug Reference",. 36th edn. London. pp. 837-841.

Thulasamma, P.; Venkateswarlu, P. (2009). Spectrophotometric method for the determination of metronidazole in pharmaceutical pure and dosage forms. Rasayan J. Chem. 2(4), 865-868. 